\title{
Who occupies disability?
}

\author{
Nick Pollard ${ }^{\mathrm{a}}$, Pamela Block ${ }^{\mathrm{b}}$ \\ aDepartment of Occupational Therapy and Vocational Rehabilitation, Sheffield Hallam University, \\ South Yorkshire, United Kingdom. \\ ${ }^{b}$ Stonybrook School of Health Technology and Management, Stony Brook University, New York, \\ United States of America.
}

\begin{abstract}
Locating occupational therapy within gendered and racialized systems of power, the authors consider the intersectional nature of critical disability studies discourse and the need for occupational therapy to incorporate such values into practice. This article discusses ways in which occupational therapy as a profession and individual therapists can align with or resist the economic determination which has come to dominate medical systems. It considers some of the political background to the history of the profession and its relationship with power. This positioning of the profession is explored against the impact of neoliberal economic policy on health, rights, service delivery and disability, and against some key issues, the pressure of ageing populations and the positon of occupational therapists as women professionals. Current policies present a critical challenge to central occupational therapy tenets. Occupational therapists may find themselves working both in alliance with disabled people and disability activists, and against them.
\end{abstract}

Keywords: Occupational Therapy, Power, Politics, Economics.

\section{Quem ocupa a deficiência?}

Resumo: Localizando a terapia ocupacional dentro de seu gênero e radicalizando os sistemas de poder, os autores consideram a natureza interseccional do discurso de estudos de deficiência crítica e a necessidade da terapia ocupacional incorporar tais valores no interior de sua prática. Este artigo discute maneiras pelas quais a terapia ocupacional como uma profissão e os terapeutas ocupacionais individualmente podem alinhar-se ou resistir à determinação econômica que passou a dominar os sistemas de saúde. Considera-se alguns dos antecedentes políticos da história da profissão e sua relação com o poder. Este posicionamento da profissão é explorado contra o impacto da política econômica neoliberal sobre a saúde, os direitos, a prestação de serviços e a deficiência, e contra algumas questões-chave, como a pressão pelo envelhecimento da população e a posição de terapeutas ocupacionais como profissão de mulheres. As políticas atuais apresentam um desafio crítico aos princípios centrais da terapia ocupacional. Terapeutas ocupacionais podem encontrar-se trabalhando tanto em aliança com as pessoas com deficiência e militantes deste campo como contra eles.

Palavras-chave: Terapia Ocupacional, Poder, Política, Economia. 


\section{Introduction}

'What is a good life and how should it be lived?' is one of the fundamental ethical questions in many areas of healthcare, particularly where people have long term disabling conditions. Occupational therapists are amongst a number of professionals whose judgements determine how people living with disability can manage an answer. There are around 500,000 occupational therapists in the World Federation of Occupational Therapists member organizations (WORLD..., 2016), an archipelago of professionals who together approximate a city, predominantly of women, of the size of Sheffield, in the UK, or Albuquerque, NM, in the USA. This city of occupational therapists claims values of occupational justice which closely aligned to disability justice, access to meaningful occupation as a human right; which have been expressed as 'doing, being, becoming and belonging' coined by Wilcock (1998) to which Rebeiro added "belonging" (2001) .

These complex and contradictory influences on the broader occupational and practice context require critical and analytical attention. Bruce (2014, p. 18) uses the term "a composite life opportunity" to describe

[...] doing or being which is not reducible to a particular level or mode of functioning of the body and mind. It is composite in the sense that it may be realised in many different ways, rather than simply through the facilitation of a particular level or mode of functioning of the body and mind such as walking, hearing or seeing. Examples are keeping a diary, being educated, playing, taking children to the playground, enjoying a cultural performance, cooking a meal or driving a car.

Such modes of doing and being involve complex and alternative activities. There are many ways to cook a meal which may not be captured through a functional assessment of skills; many ways to become educated that may not involve formal examination. In areas of human occupation this composite nature suggests a cultural depth and complexity which cannot be easily reduced to a treatment activity, or an object of assessment. There are many claims to the profession's uniqueness which rest on a holistic concern with occupation. Many approaches and models recognize that occupation is interactive with an environment, a transactive context. A pertinent example might be Bailey's (2009, p. 248) discussion of how people with disability "do healthcare" to navigate the systems which offer them forms of care and negotiate how they can make use of what is offered as practice. She suggests that this process involves conceptions of impairment based in embodied experience rather than in professional or academic discourses. This direct first-person or witness experience offers a counterpoint to academic forms of discourse which tend to represent elite perspectives and syntheses of experiences, and relies on a personal statement of positioning which indicates the witness's authority to represent themselves. The occupational therapy profession has to assert its agency but also needs to listen closely to its allies amongst people with disabilities. Together they can engage in critical intersectional analysis of all the power relations apparent in the social, political and cultural processes around the delivery of health and social care (CLOUSTON, 2014; EREVELLES, 2002, 2011; HAMMELL; IWAMA, 2012; HAMMELL, 2009, 2015a, 2015b; MINGUS, 2010).

\section{Taking Position}

In their account of the American history of occupational therapy Frank and Zemke (2008) argued that its leaders, particularly Eleanor Clarke Slagle, pursued alliances with a conservative medical profession to negotiate its place in the healthcare pantheon. The result, which allowed occupational therapists professional status but under the aegis of medicine, was the moment of its uncoupling from the collaborative ideas of Deweyan pragmatism which might otherwise have enabled an alliance with people with disabilities. This might have been laudable, but may not have sustained the development of occupational therapy. Eleanor Clarke Slagle was a powerful woman able to use her Republican party social connections to advance the nascent profession (FRANK; ZEMKE, 2008). Peters (2011) revealed how another elite group of women within the profession used their powerful social connections similarly to build the status of occupational therapy in the late mid $20^{\text {th }}$ century. Without this work, occupational therapy might not have the recognition it currently has. However one of those initially involved in the development of the profession had been Clifford Beers, whose experience of mental ill health led him to set up the mental hygiene movement. The process of lobbying for power and bargaining positions meant that the profession had left behind its origins in social activism and Christian socialism which were responses to the evident inequality in health prevailing in $19^{\text {th }}$ century Western society. In the early $21^{\text {st }}$ century the same issues of inequality continue to affect the promotion of health and the 
lives of those with disability. Practitioners often find themselves in situations where they are expected to manage the restrictions imposed on health services through economic austerity (TOWNSEND, 1993), and arguably to co-operate with the processes of disenfranchising disabled people. Writing about the poignant and inspirational example of Anne Lang Etienne as a 'dissident' occupational therapist Rachel Thibeault said, "Competent occupational therapists should first be decent human beings and decent citizens" (THIBEAULT, 2002, p. 202). Occupational therapists find themselves in an ethical dilemma, but are bound by their employment contracts, mortgages and pensions to the dominant fiscal discourses which operate in society (HAMMELL, 2007).

\section{Neoliberal Fragmentations}

In his book Thieves of virtue (2012) Tom Koch sets out how the ethics of the market place have come to dominate global healthcare. The operation of healthcare on market lines, on the basis of the ability of the patient to pay for services, and the design of services to meet what the patient may want, rather than need, have always been an important component of provision, even where there are state services such as the UK's National Health Service. Managers of health services and education must be concerned with cost efficiency and market realities, since no service can be sustained if it overspends its budget.

However, the ideological principles of the free market, low taxation, and reducing the burden of government are enduring and key traditional elements of politically conservative party programs. Healthcare is a huge and costly responsibility of governments, so tends to be a key target for policy innovation. Measures to reduce the cost of healthcare have been advanced with increased vigor since the 2008 global economic crisis, and many of them involve adopting systems approaches from commercial corporations (FUCHS, 2016; GAFFNEY, 2015; KOCH, 2012). But the new market processes do not produce tangible improvements (ACKROYD; KIRKPATRICK; WALKER, 2007; MENZIES; NEWSON, 2007). They seem more aligned to the classical neoliberal tactics of fragmenting institutions for the selling off of profitable elements, leaving an unprofitable core, as health and disability support services are opened up to aggressive market forces (DUROCHER et al., 2016). There is a tangible gap between the rhetoric of government and the qualities of health service provision, with some sectors, such as care of the older population and long term community care, in crisis, while other specialisms such as the management of neurological trauma, forensic care and specialized psychiatric services appear to be growth areas for business development.

The protection of the health of the people has ceased to be the first duty of government. The first duty now appears to be the health of the market.

\section{Critical Work}

Disengagement with health and social care in the free market has led to rising health inequality (WILKINSON; PICKETT, 2011), an issue which has a direct impact on the relationship between occupational therapy and disability activism and scholarship. Over much of the $20^{\text {th }}$ century medical power determined the status quo in health services and so it was natural that the profession should seek to align with biomedical rather than social priorities (FRANK; ZEMKE, 2008). However, there has been increasing recognition of the gap between occupational therapy's self perception of its value and underpinning theories which serve increasingly corporatized health and social care systems and the profession's connection with the needs of people with disabilities (KIELHOFNER, 2005; BLOCK et al., 2016).

Some of this concern has been expressed through concepts such as occupational justice (TOWNSEND, 1993), an emphasis on life quality, meaning and purpose through occupational science (YERXA, 1990), particularly the work of Wilcock (1998, 2006), Hitch, Pepin e Stagnitti (2014). These ideas have led to the expression of transformational goals and a political reorientation of the profession (WATSON; SWARTZ, 2004; WHITEFORD; WRIGHT-ST CLAIR, 2005; KRONENBERG; ALGADO; POLLARD, 2005; POLLARD; SAKELLARIOU; KRONENBERG, 2008; KRONENBERG; POLLARD; SAKELLARIOU, 2011; POLLARD; SAKELLARIOU, 2012; DOS SANTOS; DONATTI, 2014; SAKELLARIOU; POLLARD, 2016) including some scholarly collaboration with disability authors (e.g. WATSON; SWARTZ, 2004; BLOCK et al., 2016). The influence of this literature on the profession's thinking about itself is still partial and evolving. Some of these contributions are based in social occupational therapy practices which have developed for over forty years (LOPES; MALFITANO, 2016), but are hardly recognized in the Anglophone literature. Many of the ways in which disability is recognized, even in disability scholarship, are deeply problematized (MINICH, 2016). Despite the focus of occupational 
therapy on the problems of managing disability in everyday life there is still much theoretical and philosophical underpinning to be done in order to unravel the nuances behind the experience that people have of services (HAMMELL, 2009, 2015a, 2015b; DUROCHER; GIBSON; RAPPOLT, 2014; DUROCHER; RAPPOLT; GIBSON, 2014). While these debates take place, it will actually be cost effectiveness and efficiency that makes an impact on the financial and medical hegemonic structures which determine the markets for occupational therapy services (NILSSON; TOWNSEND, 2010) or in which the wider needs of people with disabilities are recognized (BLOCK et al., 2016).

The prevailing neoliberal ideology appears to recognize no counterargument to its simplistic economic imperative for all society's needs. Occupational therapists have drawn on transdisciplinary economists such as Max-Neef $(2005,2010)$ to indicate the importance of human values (DUNCAN; ALSOP, 2006; WATSON, 2006). Societies overlook the capacity of people with disability, increasing their marginalization, and there are protest movements led by disabled people to articulate their frustration (SHAPIRO, 1993; CURTIS et al., 2011; DELLAR, 2014; BEN-MOSHE, 2016; DUPREE, 2016; TAYLOR et al., 2016; MOORE; GRAY-GARCIA; THROWER, 2016).

Although there is criticism of intransigence and insensitivity in the profession (BAILEY, 2009) there have been occasions when occupational therapist practitioners and students have stood with disabled people at important activist moments. One example of this might be the protests against the failure to implement Section 504 of the 1973 Rehabilitation Act led to the US disability rights movement's occupation of the federal office building in San Francisco in April 1977, a significant point in disability rights history (ERVIN, 1986). This was achieved with the help of occupational therapy students who volunteered to provide personal assistance throughout the 25 days of occupation (private conversation with Christine Peters). Critical work is not just about theoretical sophistication. More recently, occupational therapist Denise Nepveux (2016) worked in alliance with senior citizens in Syracuse, New York who protested the closure of their inner city community center. We assert, in alliance with disability justice activists, that it is in these moments of political activism that critical theory development takes place. Disability Justice activists assert that it is not truly "critical" work if intersectional identities and power relationships -- meaning gender, race, disability, sexuality and professional/personal identities -- are not fully taken into account (BEN-MOSHE; CHAPMAN; CAREY, 2014; BURCH, 2014; EREVELLES, 2002, 2011; MINGUS, 2010; NISHIDA, 2016). Scholars who do not credit the work in these activist spaces are simultaneously appropriating and erasing both the struggles and the intellectual properties of others, interposing their own interpretation instead of allowing people with direct lived experience to have their voice. It is best for academics to work in alliance with activists to find the means to provide their key experience and knowledge directly rather than reporting on it second hand - even if appropriately cited.

Recent proposals for the future of healthcare in the global north seem to accept the retreat of city and state supported health systems such as the NHS or US city regions from some areas of care, and in their place encourage a greater role from charities and the voluntary sector, even from the voluntary efforts of patients themselves (NHS ENGLAND, 2014, 2016; HERRIN, 2013). The commissioning of the third sector to provide services which reflect community needs has the appearance of enlightened community engagement, but there are hints of a reductive cynicism. "Free care at the point of delivery" (NHS England, 2015) does not apply to people with disabilities. An agenda of individualistic solutions shifts responsibility from government to the 'consumer' and the 'volunteer' in a marketized disruption of social justice, on both sides of the Atlantic (MLADENOV; OWENS; CRIBB, 2015; GAFFNEY, 2015). An example is the UK's personalisation of health care in which individuals manage their own budgets to pay for their own care. In the US some people have obtained a similar right to control their funding for services. This gives them the ability to hire, fire and train employees instead of taking whoever is assigned within a system of care. However this control often comes at the cost of stability, for if workers cancel a shift, there is no agency to assign a backup worker from a pool of employees. The disabled person must appeal to interdependent networks of current/former workers, family and friends, or simply do without. In situations where the employees who cancel provide a life-sustaining role, doing without comes at risk to wellbeing and even survival (DUPREE, 2016; NEPVEUX, 2016).

In the UK a flexible system of deskilled and low paid workers, often occupying roles that were once carried out by district nurses, visit people in their homes for 15 minute calls. Instead of providing rehabilitation and working for independence, the 
focus is on maintenance, but such fleeting visits often leave no time for these clients to be adequately fed, medicated, washed, watered, and toileted (UNISON, 2015). There is no space in the workers' schedule, and no physical space (because there is no office base to return to) for these workers to even evaluate and reflect on the emotional aspects of the care they give (NEEDHAM, 2015; UNISON, 2015). Nor is there personal space at home because work has become prioritized over other aspects of life (CLOUSTON, 2014).

Of course better and efficient care is necessary, but there is a danger of reducing people to dehumanised units. Each delay accumulates costs in a system where financial accountability has been devolved to each public or private service providing organization and many staff within them to manage responsibly. This is despite the increasing difficulty of doing so with reduced budgets and rising costs (MACLEAN, 2015; MLADENOV; OWENS; CRIBB, 2015; NHS ENGLAND, 2013). Therefore, as Koch (2012) points out, the ethic of care has been replaced by one which takes a utilitarian view of the need to maintain the system for all the people needing services, as governments may not be able to meet the debts run up by hospitals and care agencies or replace the services of those which go bankrupt. Part of the real cost seems to be being picked up by the people working in the system (BORIS; KLEIN, 2012; CLOUSTON, 2014; UNISON, 2015), and the other part is being picked up by the people paying for the service they receive, and through its impact on society (WILKINSON; PICKETT, 2011).

\section{The Cost of Ageing}

The problem of the affordability of social care with an increasingly complex ageing population, and a rise in conditions such as diabetes, obesity, heart conditions and cancers, many of which are related to lifestyle, is generating considerable anxiety amongst governments. The problem is the long term taper of demand that these health issues represent. One example is the division of health and social care for older people. In the UK social care is not regarded as a health cost. Instead of central government paying for this care, the separation of social care became a local responsibility which was funded by local councils. The cost falls on the local community rates and taxes, not the national tax bill, the responsibility becomes that of local government, not national government, an issue which is developing into a national crisis. Populations are increasing globally, but in many Western countries they are aging, particularly in rural areas (HOSPERS; REVERDA, 2015). In the US and UK the number of healthcare workers is declining, because many of them are due to retire (HARRINGTON; HEIDKAMP, 2013; ADDICOTT et al., 2015). Healthcare systems, particularly state systems, have had to meet increasing demands and experience shortages of skills that are filled through overseas recruitment even though this often has the effect of draining economically poorer countries of professionals in whom they have invested for their own needs and at the expense of local disabled people (CONNELL; STILWELL, 2006; EREVELLES, 2011; MAYBUD; WISKOW, 2006).

\section{Women's Work and Power: Contradictory Pressures}

Unfortunately the history of the profession has rather worked against its purpose. Typically occupational therapy was introduced into many countries as a suitable profession for well disposed practical women with a little knowledge of medical matters and a friendly and approachable manner. Occupation based interventions take time to implement, and on the whole have tended to be applied in areas where patients were in long term care, i.e. where they needed activity, and to whom little else was being offered. Typically, practitioners were not taken seriously by other professionals because occupational therapy did not involve medical procedures or weighty decisions, it often did not matter if patients missed interventions. Perhaps occupational therapists themselves accepted the culture of institutions and the lack of quality evaluation and research which perpetuated this impression. Occupational therapists have long struggled to secure the qualifications, the mechanisms and the funds to research their interventions. This was indicative of a lack of power. To attain bargaining power, occupational therapists sometimes positioned themselves as one of the groups of allied health professions. While this reflected the multidisciplinary nature of intervention, it plays into another neoliberal demand for flexibility and the ability of workers to meet specific targets, for example, waiting times, contact hours, or numbers of patients seen per day (see Nishida's concept of hyper-productivity) as an aspect of cost management, rather than patient need (HYDE et al., 2016; NISHIDA, 2016). The skill base of the professional is not then so significant as their ability to process people through the health system. There have been several training schemes over the recent history of health services which aim 
to produce such workers with a minimal level of qualification. Without an adequate evidence base to meet all the holistic claims that occupational therapists make for their skills (HAMMEL et al., 2015) and a reducing of range of demands in the practice arena as people speed through the system, the value of the profession is less visible.

While occupational therapists have rather uncritically claimed a professional ethos of client centered practice, this has been challenged by commentators in the disability movement, some of whom suggest that since occupational therapists depend on people with disability for their role, they are in fact the client (MARCUS; KASNITZ; BLOCK, 2016). In the extreme, some even refer to occupational therapists, physical therapists, special educators, carers, and related fields as "PLODOS" or "People Living Off Disability Oppression.” None the less, occupational therapists have tried to manage their relationship with the people they work with in a way which is on the whole egalitarian, and has the intent of providing a space for creative exploration even within an environment of incarceration (MIRZA, 2014), but the complexities of this relationship have never been adequately explored. The perspective offered is that of the occupational therapist.

Where does this situate the profession? In her account of experience as a mixed race occupational therapist, Lily Owens (2016) discusses the phenomenon of "seeing white". She derives this from the work of Nelson (2007), who is describing the interface of Western and aboriginal values in Australian practice. The profession has developed through its powerful women leaders into a group of people who are well ensconced in dominant middle class cultures (e.g. PETERS, 2011), but still dependent on male hegemonic power. It is a fragile relationship, one result of which in most countries occupational therapy is white, middle class and feminine. The point that Lily Owens raises is that it is hard to see beyond the narrow field of vision this offers. In disability studies, nothing is considered critical theory if, in addition to disability, it does not directly include theoretical perspectives that address the intersections of gender, race, class, ethnicity, sexuality and other marginalities. This is disability justice (MINGUS, 2010).

Occupational therapy has to find out whether it can flourish in the new aggressive marketization of health care. It has tended to shelter itself under the wing of male hegemony by upholding most of its gentlemanly values. But these values are only the veneer on a tough disciplinarian which determines winners and losers, which people worth investing in and which enterprises (and lives!) need to fail. As Koch suggests (2012), ideas such as euthanasia, eugenics and all the bogeys of earlier unpleasant political ideologies are beginning to resurface as unproblematic market logic.

\section{Finding Directions for Practice}

Such a prevailing attitude in policy makes it more difficult to be client centered, indeed it reveals the concept itself to be problematic (HEFFRON; HAMMEL, 2016). A practice centered on the medical complexities of individual atomized clients does not recognize critical perspectives in which people are marginalized in complex society which practices complicated and indirectly punitive measures against those who cannot compete in the market place (GAFFNEY, 2015). Being unable to compete is a condition associated with being old. Many of the issues which an older population have to manage concern poverty. Whether to heat or eat, for example, being unable to get out of the house because transport is unaffordable, staying in one room to keep the heat in, a slow living death eked out in 15 minute social care calls. People are left untoileted, or unfed, or needing medication which is mal-administered, and often say that they want to die (POLLARD, 2015). Students report examples of this each year when they return from field work placements or from the part time care work they do to fund themselves. Many of these issues are not insurmountable social problems, but require adequate funding for more detailed approaches to care. The UK government's five year forward view (NHS ENGLAND, 2014) suggests delivering care through groups of patients organized as peers at a community level. This apparently hands power back to the community, or the disabled person, but does so in ways that suggest that people will be left to manage with their own untrained and not necessarily reliable resources. This, as Herrin (2013) and Gaffney (2015) have noted is also occurring in the US.

If occupational therapists are concerned with building reflexive and critical alliances with clients, then they will need to take account of the strong sense amongst disability scholars and activists that such work should directly address the intersectional experiences of disabled people, and in particular experiences of disabled people of color, as well as gendered and sexual experiences of disability (MINICH, 2016). Critical work within disability studies recognizes the concept of "Nothing About Us without Us," as central. Some of the most meaningful 
critical practices within disability communities are not happening in academia, they are happening in activist spaces. Activists' writings may therefore represent some of the most important critical work available of relevance to both disability studies and occupational therapy (BLOCK et al., 2016).

In the context of the relationship between occupational therapists and the people they support, a focus on critically reflexive thought and practice could be developed by discussing the differences between, for example, therapists experiences and those of the people they support within their communities. This discussion can take place in a community space outside the clinical setting. It may be the means by which the role of the occupational therapist can be understood and even renegotiated to better accommodate what a person may need - in a better relationship to the communities they may live in. Allowing a critical discussion to develop in a neutral space and which does not privilege the professional above experience is a risky and uncomfortable enterprise. Block et al. (2016, p. 8) assert that the

[...] discomfort zone is where we acknowledge and respect boundaries while at the same time pushing them. This is an ongoing struggle when moving between activist versus scholarly, clinical, and professional formulations.

Their point is related to the antiracist discomfort pedagogy emerging from South Africa (ZEMBYLASA, 2015). A further step might be moving from neutral spaces to joining each other in alliance in activist spaces meaningful to both groups. We reflect again on the OT students who supported the disability rights activists in San Francisco in 1977.

In this kind of space professional and elite status has to be set aside, and retreating into "seeing white" is not an option that can be adopted without breaching the contract. It will lead people into territory that is beyond current theory, may even seem atheoretical, but is in fact the beginning of new theory. The evidence base for the supremacy of the market which is driving healthcare practices is well established through much of recorded history. It is true that the market has been supreme all this time, but it is not always supreme all the time. Markets collapse, material things are lost, societies are deconstructed and the consequences are evident in many economically poor countries, and in many marginalized pockets within wealthy ones. There are no resources for these pockets, people have to make them, often without any prevailing theory, on the basis of the assets which they can construct themselves. It is how people survive, recover, come back and regain control, autonomy, or find interdependence.

\section{References}

ACKROYD, S.; KIRKPATRICK, I.; WALKER, R. M. Public management reform in the UK and its consequences for professional organization: a comparative analysis. Public Administration, Malden, v. 85, n.1, p. 9-26, 2007.

ADDICOTT, R. et al. Workforce planning in the NHS. London, 2015. Available from: <https:// www.researchgate.net/profile/Joni_Jabbal/publication/276684035_Workforce_planning_in_the_NHS/ links/555a0ae108aeaaff3bfab844.pdf>. Access on: 27 feb. 2017.

BAILEY, R. Disabled people's healthcare encounters. Edinburgh, 2009. Available from: <https:/www.era.lib. ed.ac.uk/bitstream/handle/1842/4238/Bailey2009. pdf?sequence=2>. Access on: 27 feb. 2017 .

BEN-MOSHE, L.; CHAPMAN, C.; CAREY, A. (Ed.). Disability incarcerated. New York: Palgrave MacMillan, 2014.

BEN-MOSHE, L. Movements at war? Disability and anti-occupation activism in Israel. In: BLOCK, P. et al. Occupying disability: critical approaches to community, justice and decolonizing disability. New York: Springer, 2016. p. 47-61.

BLOCK, P. et al. (Ed.). Occupying disability: critical approaches to community, justice and decolonizing disability. New York: Springer, 2016.

BRUCE, A. Which entitlements and for whom? The convention on the rights of persons with disabilities and its ideological antecedents. Lund: Lund University, 2014.

BORIS, E.; KLEIN, J. Caring for America: home health workers in the shadow of the welfare state. New York: Oxford University Press, 2012.

BURCH, S. Dislocated histories: the canton asylum for insane indians. Women, Gender, Families of Color, Illinois, v. 2, n. 2, p. 141-162, 2014.

CLOUSTON, T. J. Whose occupational balance is it anyway? The challenge of neoliberal capitalism and work-life imbalance. British Journal of Occupational Therapy, London, v. 77, n. 10, p. 507-515, 2014.

CONNELL, J.; STILWELL, B. Merchants of medical care: recruiting agencies in the global health care chain. In: KUPTSCH, C. (Ed.). Merchants of Labour. Geneva: International Institute for Labour Studies/International Labour Office, 2006. p. 239-253.

CURTIS, T.; DELLAR, R.; ESTHER, L. Mad pride. London: Chipmunka Publishing, 2011. 
DELLAR, R. Splitting in two: mad pride \& punk rock oblivion. London: Unkant Publishing, 2014.

DOS SANTOS, V.; DONATTI, A. D. Questóes contemporânea da Terapia Ocupacional na América do Sul. Curitaba: Editora CRV, 2014.

DUPREE, N. My world, my experiences with occupy Wall Street and how we can go further. In: BLOCK, P. (Ed.). Occupying disability: critical approaches to community, justice, and decolonizing disability. New York: Springer, 2016. p. 225-234.

DUROCHER, E.; GIBSON, B. E.; RAPPOLT, S. Occupational justice: a conceptual review. Journal of Occupational Science, London, v. 21, n. 4, p. 418-430, 2014.

DUROCHER, E.; RAPPOLT, S.; GIBSON, B. E. Occupational justice: future directions. Journal of Occupational Science, London, v. 21, n. 4, p. 431-442, 2014.

DUROCHER, E. et al. Ethical tensions related to systemic constraints occupational alienation in Occupational Therapy practice. OTJR: Occupation, Participation and Health, United States, v. 36, n. 4, p. 216-226, 2016.

EREVELLES, N. (Im) material citizens: cognitive disability, race and the politics of citizenship. Disability Culture Education, United States, v. 1, n. 1, p. 5-25, 2002.

EREVELLES, N. Disability and difference in global contexts: enabling a transformative body politic. New York: Palgrave Macmillan, 2011.

ERVIN, M. The 25 day siege that brought US 504. United States, 1986. Available from: <http://www.independentliving.org/docs4/ervin 1986.html>. Access on: 27 feb. 2017.

FRANK, G.; ZEMKE, R. Occupational therapy foundations for political engagement and social transformation. In: POLLARD, N.; SAKELLARIOU, D.; KRONENBERG, F. (Ed.). A political practice of Occupational Therapy. Edinburgh: Churchill Livingstone, 2008. p. 111-136.

FUCHS, C. Neoliberalism in Britain: from thatcherism to cameronism. Communication, Capitalism and Critique, London, v. 14, n. 1, p. 163-188, 2016. Available from: <http://triple-c.at/index.php/tripleC/article/ view/750/795>. Access on: 11 oct. 2016.

GAFFNEY, A. The neoliberal turn in American health care. International Journal of Health Services, United States, v. 45, n. 1, p. 33-52, 2015.

HAMMEL, J. et al. A scholarship of practice revisited: creating community-engaged occupational therapy practitioners, educators, and scholars. Occupational Therapy in Health Care, Boca Raton, v. 29, n. 4, p. 352369, 2015.

HAMMELL, K. W. Client-centred practice: ethical obligation or professional obfuscation. British Journal of Occupational Therapy, London, v. 70, n. 6, p. 264-266, 2007.
HAMMELL, K. W. Sacred texts: a sceptical exploration of the assumptions underpinning theories of occupation. Canadian Journal of Occupational Therapy, Ottowa, v. 76, n. 1, p. 6-13, 2009

HAMMELL, K. R. H.; IWAMA, M. K. Well-being and occupational rights: an imperative for critical occupational therapy. Scandinavian Journal of Occupational Therapy, London, v. 19, n. 5, p. 385-394, 2012.

HAMMELL, K. R. H. Client-centred occupational therapy: the importance of critical perspectives. Scandinavian Journal of Occupational Therapy, London, v. 22, n. 4, p. 237-243, 2015a.

HAMMELL, K. R. H. Respecting global wisdom: enhancing the cultural relevance of occupational therapy's theoretical base. British Journal of Occupational Therapy, London, v. 78, n. 11, p. 718-721, 2015 b.

HARRINGTON, L.; HEIDKAMP, H. The aging workforce: challenges for the health care industry workforce. New Jersey: NTAR Leadership Center, 2013. Available from: <https:/www.dol.gov/odep/pdf/NTAR-AgingWorkforceHealthCare.pdf>. Access on: 1 mar. 2017.

HEFFRON, J.; HAMMEL, J. Participation values and barriers as experienced by adults with intellectual and developmental disabilities. American Journal of Occupational Therapy, United States, v. 70, n. 4, 7011505115p1, 2016. Supplement 1.

HERRIN, R. The impact of the affordable care act on the safety-net. A focus on two community-based clinics serving latin@immigrants in the greater New Orleans Region. 2013. $62 \mathrm{f}$. Thesis (Doctor in Urban and Regional Planning) - University of New Orleans, New Orleans, 2013.

HITCH, D.; PEPIN, G.; STAGNITTI, K. In the footsteps of Wilcock, part one: the evolution of doing, being, becoming, and belonging. Occupational Therapy in Health Care, London, v. 28, n. 3, p. 231-246, 2014.

HOSPERS, G. J.; REVERDA, N. Managing population decline in Europe's urban and rural areas. Heidelberg: Springer, 2015.

HYDE, P. et al. Deconstructing the Welfare State: managing healthcare in the age of reform. Abingdon: Routledge, 2016.

KIELHOFNER, G. Rethinking disability and what to do about it: disability studies and its implications for occupational therapy. American Journal of Occupational Therapy, United States, v. 59, n. 5, p. 487-496, 2005.

$\mathrm{KOCH}, \mathrm{T}$. Thieves of virtue: when bioethics stole medicine. Cambridge: MIT Press, 2012.

KRONENBERG, F; ALGADO, S.; POLLARD, N. (Ed.). Occupational Therapy without borders: learning from the spirit of survivors. Edinburgh: Elsevier Science, 2005.

KRONENBERG, F; POLLARD, N.; SAKELLARIOU, D. (Ed.). Occupational therapies without borders: 
towards an ecology of occupation-based practices. Edinburgh: Elsevier Science, 2011.

LOPES, R. E.; MALFITANO, A. P. S. (Ed.). Terapia ocupacional social: desenhos teóricos e contornos práticos. São Carlos: EdUFSCar, 2016.

MACLEAN, J. Recovery-focussed leadership in the NHS. Mental Health and Social Inclusion, United Kingdom, v. 19, n. 2, p. 87-94, 2015.

MARCUS, N.; KASNITZ, D.; BLOCK, P. If disability is a dance, who is the choreographer? A conversation about life occupations, art, movement. In: BLOCK, P. et al. Occupying disability: critical approaches to community, justice and decolonizing disability. New York: Springer, 2016. p. 347-358.

MAX-NEEF, M. A. Foundations of transdisciplinarity. Ecological economics, United States, v. 53, n. 1, p. 5-16, 2005.

MAX-NEEF, M. A. The world on a collision course and the need for a new economy. Ambio, Oslo, v. 39, n. 3, p. 200-210, 2010.

MAYBUD, S.; WISKOW, C. Care trade: the international brokering of health care professionals. In: KUPTSCH, C. (Ed.). Merchants of labour. Geneva: International Institute for Labour Studies/International Labour Office, 2006. p. 224-238.

MENZIES, H.; NEWSON, J. No time to think. Time \& Society, Germany, v. 16, n. 1, p. 83-98, 2007.

MINGUS, M. Reflections on an opening: disability justice and creating collective access in Detroit. 2010. Available from: <https://inciteblog.wordpress.com/2010/08/23/ reflections-from-detroit-reflections-on-an-openingdisability-justice-and-creating-collective-access-in-detroit/>. Access on: 7 sept. 2016.

MINICH, J. A. Enabling whom? Critical disability studies now. Lateral, Chicago, v. 5, n. 1, 2016. Available from: <http://csalateral.org/wp/issue/5-1/forumalt-humanities-critical-disability-studies-now-minich/>. Access on: 7 sept. 2016.

MIRZA, M. Refugee camps, asylum detention, and the geopolitics of transnational migration: Disability and its intersections with humanitarian confinement. In: BEN-MOSHE, L.; CHAPMAN, C.; CAREY, A. (Ed.). Disability Incarcerated. New York: Palgrave MacMillan, 2014. p. 217-236.

MLADENOV, T.; OWENS, J.; CRIBB, A. Personalisation in disability services and healthcare: a critical comparative analysis. Critical Social Policy, United Kingston, v. 35, n. 3, p. 307-326, 2015.

MOORE, L. F.; GRAY-GARCIA, L.; THROWER, E. H. Black \& blue: policing disability \& poverty beyond Occupy. In: BLOCK, P. et al. (Ed.). Occupying disability: critical approaches to community, justice and decolonizing disability. New York: Springer, 2016. p. 295-318.
NEEDHAM, C. The spaces of personalisation: place and distance in caring labour. Social Policy \& Society, Cambridge, v. 14, n. 3, p. 357-369, 2015.

NELSON, A. Seeing white: a critical exploration of occupational therapy with Indigenous Australian people. Occupational Therapy International, Chichester, v. 14, n. 4, p. 237-255, 2007.

NEPVEUX, D. M. Refusing to go away: the ida benderson seniors action group. In: BLOCK, P. et al. (Ed.). Occupying disability: critical approaches to community, justice and decolonizing disability. New York: Springer, 2016. p. 175-194.

NILSSON, I.; TOWNSEND, E. Occupational justiceBridging theory and practice. Scandinavian Journal of Occupational Therapy, Scandinavian, v. 17, n. 1, p. 57 63, 2010.

NHS ENGLAND. Guide to the healthcare system in England. 2013. Available from: <https://www.gov.uk/ government/uploads/system/uploads/attachment_data/ file/194002/9421-2900878-TSO-NHS_Guide_to_ Healthcare_WEB.PDF>. Access on: 7 sept. 2016.

NHS ENGLAND. Five year forward view. 2014. Available from: <https://www.england.nhs.uk/wp-content/ uploads/2014/10/5yfv-web.pdf $>$. Access on: 7 sept. 2016.

NHS ENGLAND. Principles and values that guide the NHS. 2015. Available from: <http://www.nhs.uk/ NHSEngland/thenhs/about/Pages/nhscoreprinciples. aspx>. Access on: 7 sept. 2016

NHS ENGLAND. The five year forward view for mental health. 2016. Available from: <https://www.england. nhs.uk/wp-content/uploads/2016/02/Mental-HealthTaskforce-FYFV-final.pdf>. Access on: 7 sept. 2016.

NISHIDA, A. Neoliberal academia and a critique from disability studies. In: BLOCK, P. et al. (Ed.). Occupying disability: critical approaches to community, justice and decolonizing disability. New York: Springer, 2016. p. 145-158.

OWENS, L. Our professional existence is political: critical reflections on 'Seeing White' in Occupational. In: SAKELLARIOU, D.; POLLARD, N. (Ed.). Occupational Therapies without borders: integrating justice with practice. Edinburgh: Elsevier Science, 2016. p. 194-202.

PETERS, C. Powerful Occupational Therapists: a community of professionals, 1950-1980. Occupational Therapy in Mental Health, New York, v. 27, n. 3-4, p. 199-410, 2011. http://dx.doi.org/10.1080/016421 2X.2011.597328.

POLLARD, N. Community-BASED models of practice to address late life inequities: examples from the UK. In: BARNEY, K.; PERKINSON, M. (Ed.). Occupational Therapy with aging adults: promoting quality of life through collaborative practice. New York: Elsevier, 2015. p. 455-468. 
POLLARD, N.; SAKELLARIOU, D. (Ed.). Politics of occupation-centred practice. Oxford: Wiley, 2012.

POLLARD, N.; SAKELLARIOU, D.; KRONENBERG, F. (Ed.). A political practice of Occupational Therapy. Edinburgh: Elsevier Science, 2008.

SAKELLARIOU, D.; POLLARD, N. (Ed.) Occupational Therapies without borders: integrating justice with practice. Edinburgh: Elsevier Science, 2016.

SHAPIRO, J. P. No pity: people with disabilities forging a new civil rights movement. New York: Random House, 1993.

TAYLOR, S. et al. Krips, cops and occupy: reflections from Oscar Grant Plaza. In: BLOCK, P. et al. (Ed.). Occupying disability: critical approaches to community, justice and decolonizing disability. New York: Springer, 2016. p. 15-29.

THIBEAULT, R. In praise of dissidence: Anne LangÉtienne (1932-1991). Canadian Journal of Occupational Therapy, Ottawa, v. 69, n. 4, p. 197-203, 2002.

TOWNSEND, E. Occupational therapy's social vision. Canadian Journal of Occupational Therapy, Ottawa, v. 60, n. 4, p. 174-184, 1993.

UNISON. UNISON's homecare training survey report. London, 2015. Available from: <https://www.unison. org.uk/content/uploads/2015/04/TowebUNISONsHomecare-Training-Survey-Report.pdf $>$. Access on: 11 oct. 2016.

WATSON, R. M.; SWARTZ, L. (Ed.). Transformation through occupation. London: Whurr, 2004.
WATSON, R. M. Being before doing: the cultural identity (essence) of occupational therapy. Australian Occupational Therapy Journal, Australia, v. 53, n. 3, p. 151-158, 2006.

WHITEFORD, G.; WRIGHT-ST CLAIR, V. (Ed.). Occupation and practice in context. Sydney: Churchill Livingstone, 2005.

WILCOCK, A. A. Reflections on doing, being and becoming/Reflexion sur agir, etre et devenir. Canadian Journal of Occupational Therapy, Ottawa, v. 65, n. 5, p. 248-257, 1998.

WILCOCK, A. A. An occupational perspective of health. Thorofare: SLACK Incorporated, 2006.

WILKINSON, R.; PICKETT, K. The spirit level: why greater equality makes societies stronger. London: Bloomsbury Press, 2011.

WORLD FEDERATION OF OCCUPATIONAL THERAPISTS. Member organisations of WFOT. Western Australia, 2016. Available from: <http://www.wfot. org/Membership/MemberOrganisationsofWFOT. aspx>. Access: 11 oct. 2016.

YERXA, E. J. An introduction to occupational science, a foundation for occupational therapy in the 21st century. Occupational Therapy in Health Care, United States, v. 6, n. 4, p. 1-17, 1990.

ZEMBYLASA, M. Pedagogy of discomfort' and its ethical implications: the tensions of ethical violence in social justice education. Ethics and Education, United Kingston, v. 10, n. 2, p. 163-174, 2015.

\section{Author's Contributions}

Both authors are responsible for the manuscript conception, writing and revisions. All authors approved the final version of the text. 